\title{
Review
}

Neurosignals 2013;21:259-271

DOI: $10.1159 / 000337263$
Received: June 14, 2011

Accepted after revision: February 11, 2012

Published online: May 9, 2012

\section{Neuronal Functions of Activators of G Protein Signaling}

\author{
Man K. Tse ${ }^{a}$ Yung H. Wong ${ }^{a, b}$
}

${ }^{a}$ Division of Life Science and the Biotechnology Research Institute and ${ }^{b}$ State Key Laboratory of Molecular

Neuroscience, Hong Kong University of Science and Technology, Hong Kong, SAR, China

\section{Key Words}

Activator of $\mathrm{G}$ protein signaling • Circadian rhythm •

Addiction $\cdot$ Neural plasticity $\cdot$ Asymmetric cell division .

Neurite outgrowth

\begin{abstract}
G protein-coupled receptors (GPCRs) are one of the most important gateways for signal transduction across the plasma membrane. Over the past decade, several classes of alternative regulators of $\mathrm{G}$ protein signaling have been identified and reported to activate the $G$ proteins independent of the GPCRs. One group of such regulators is the activator of $G$ protein signaling (AGS) family which comprises of AGS1-10. They have entirely different activation mechanisms for $G$ proteins as compared to the classic model of GPCR-mediated signaling and confer upon cells new avenues of signal transduction. As GPCRs are widely expressed in our nervous system, it is believed that the AGS family plays a major role in modulating the $G$ protein signaling in neurons. In this article, we will review the current knowledge on AGS proteins in relation to their potential roles in neuronal regulations.
\end{abstract}

Copyright $\odot 2012$ S. Karger AG, Basel

\begin{tabular}{ll}
\hline KARGER & $\begin{array}{l}\text { () 2012 S. Karger AG, Basel } \\
\text { 1424-862X/13/0214-0259\$38.00/0 Open access }\end{array}$ \\
E-Mail karger@karger.com & $\begin{array}{l}\text { This is an Open Access article licensed under the terms of the } \\
\text { www.karger.com/nsg }\end{array}$ \\
$\begin{array}{l}\text { Creative Commons Attribution-NonCommercial 3.0 Un- } \\
\text { ported license (CC BY-NC) (www.karger.com/OA-license), } \\
\text { applicable to the online version of the article only. Distribu- } \\
\text { tion permitted for non-commercial purposes only. }\end{array}$
\end{tabular}

\section{Introduction}

The G protein-coupled receptor (GPCR) family mediates a variety of signal transduction pathways in living organisms and its signaling mechanism has been well studied in the past several decades. Recently, a number of novel binding partners of $\mathrm{G}$ protein subunits have been reported as additional regulators to the classic mechanism of GPCR signaling. One particular group of these modulators is the activator of $\mathrm{G}$ protein signaling (AGS) family. AGS members were first identified in a functional screen for activators of heterotrimeric $G$ proteins in Saccharomyces cerevisiae $[1,2]$. The screen allowed rapid identification of proteins that activate the G $\beta \gamma$-mediated pheromone response pathway in S. cerevisiae in the absence of a pheromone-responsive GPCR [1].

AGS family members activate the $G$ protein pathways in a receptor-independent manner. Most of the family members are distinct proteins that lack structural homology between them. They are classified into three distinct groups based on their activation mechanism in the $S$. cerevisiae-based functional screen [3]. Group I contains AGS1 which activates $G$ protein signaling by acting as a guanine nucleotide exchange factor (GEF) for $\mathrm{G} \alpha_{\mathrm{i} / \mathrm{o}}$ and promotes the binding of GTP $\gamma S$ to $\mathrm{G \alpha}_{\mathrm{i} 2}$ as well as puri- 
Table 1. Neuronal functions of AGS proteins

\begin{tabular}{|c|c|c|}
\hline $\begin{array}{l}\text { AGS } \\
\text { members }\end{array}$ & Functions & Ref. \\
\hline \multicolumn{3}{|l|}{ Group 1} \\
\hline \multirow[t]{3}{*}{ AGS1 } & Circadian rhythm & $13,15,16$ \\
\hline & Damaged nerve regeneration & 97 \\
\hline & Retinal ganglion cell apoptosis & 98 \\
\hline \multicolumn{3}{|l|}{ Group 2} \\
\hline \multirow[t]{5}{*}{ AGS3 } & Addiction & $31-34$ \\
\hline & Aggresomal pathway & 35 \\
\hline & Asymmetric cell division & 36 \\
\hline & Macroautophagy & 39 \\
\hline & Membrane protein trafficking & 40 \\
\hline \multirow[t]{4}{*}{ AGS5 } & GIRK channel regulation & 57 \\
\hline & Mitotic spindle organization & $58-60$ \\
\hline & NMDA receptor trafficking & 56 \\
\hline & Phototransduction & 61 \\
\hline \multirow[t]{4}{*}{ AGS6 } & Neuronal differentiation & 92 \\
\hline & Calcium channel regulation & 94,95 \\
\hline & PDGF $\beta$ receptor regulation & 96 \\
\hline & Ras signaling regulation & 92 \\
\hline \multicolumn{3}{|l|}{ Group 3} \\
\hline \multirow[t]{6}{*}{ AGS2 } & Cilium length control & 84 \\
\hline & Cortical neurogenesis & 89 \\
\hline & Fate determination of neural progenitors & 88 \\
\hline & Neurite outgrowth & $85-87$ \\
\hline & Regulation of orexin receptor signaling & 90 \\
\hline & Rhodopsin trafficking & 99 \\
\hline
\end{tabular}

fied brain $\mathrm{G} \alpha$ proteins $[1,4]$. Group II members include AGS3 to AGS6 and they activate G protein signaling by interacting with $G \alpha_{i}$-GDP in the absence of nucleotide exchange. AGS3-6 possess at least one $G$ protein regulatory (GPR) motif, a conserved 25-30 amino acid sequence responsible for interacting with GDP-bound $G \alpha_{\mathrm{i} / \mathrm{o}}$ subunits. They are known as guanine nucleotide dissociation inhibitors (GDIs) because of their inhibitory effect on GDP dissociation from $\mathrm{G} \alpha_{i}$ subunits [5]. The GDIs stabilize the $G \alpha_{i}$ subunits in the GDP-bound state and lead to three possible outcomes: (1) Activation of G $\beta \gamma$ signaling by AGS proteins competing against $G \beta \gamma$ for $G \alpha_{i}$-GDP from the pool of heterotrimeric complexes and triggering release of $G \beta \gamma$ subunits for downstream signals; or (2) AGS $/ G \alpha_{\mathrm{i}^{-}} \mathrm{GDP}$ complex acting as a signaling molecule having specific downstream effectors; or (3) AGS/G $\alpha_{i^{-}}$ GDP complex acting as a substrate for GEF to generate $\mathrm{G}_{\mathrm{i}}$-GTP. Group III AGS is composed of AGS2, AGS7 to AGS10. The criterion for inclusion in this group is activating $G$ protein signaling via direct interaction with
Gß $\gamma$ subunits. AGS2 and AGS8 have been reported to in-

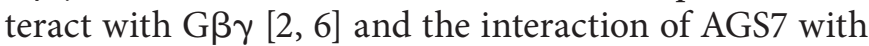
Gß $\gamma$ has been mentioned as unpublished data [7]. AGS10 encodes $G \alpha_{0}$ which is known to be a good binding partner of G $\beta \gamma$. In contrast, AGS9 has not yet been demonstrated as an interacting partner of Gß $\gamma$. AGS9 and AGS10 are classified into Group III because their properties in the yeast screen are similar to AGS2, AGS7 and AGS8 [8].

Since AGS proteins can activate $G$ proteins in a receptor-independent manner, they have the potential to regulate the majority of GPCR-mediated neuronal signaling pathways. Neuronal functions that have been reported to be regulated by AGS members are summarized in table 1 and the roles of AGS proteins will be discussed according to their regulatory functions in the nervous system. A number of excellent reviews are available for a more comprehensive analysis of the mechanistic pathway and structural properties of AGS proteins [3, 7-11].

\section{Regulation of Circadian Rhythm via AGS1}

AGS1 is also named as Dexras1, $a$ dexamethasone-inducible, ras-related protein in AtT20 cells [12] or RASD1 by the HUGO Gene Nomenclature Committee. It activates the $G \beta \gamma$-mediated yeast pheromone response pathway in the absence of GPCR [1] by serving as a GEF of $G \alpha_{i}$ [4]. AGS1 also belongs to the Ras family and contains all consensus guanine nucleotide binding regions of Ras proteins [4]. It has been suggested that guanine nucleotide binding to AGS1 is required for its proper functioning [4]. AGS1 is widely expressed in the nervous system with rhythmic expression in suprachiasmatic nucleus (SCN) [13], the protein distribution pattern of AGS1 in the central nervous system (CNS) is summarized in table 2. AGS1 is regulated by the NMDA receptor and neuronal nitric oxide synthase (nNOS) [14] and it has been reported to play a role in circadian rhythm $[15,16]$.

Since the discovery of AGS1, the mechanisms underlying its regulation and signal transduction have been extensively studied. A yeast two-hybrid study screening a cDNA library of rat hippocampus and cortex against the phosphotyrosine-binding (PTB) domain of CAPON (carboxy-terminal PDZ ligand of nNOS), a nNOS adaptor protein, has identified a fragment of rat AGS1 (amino acids 235-280) [14]. The C-terminus of AGS1 is found to interact with the N-terminal PTB domain of CAPON to form a ternary complex with CAPON and nNOS. Upon interaction, AGS1 is S-nitrosylated by NO donors at cys- 
Table 2. Distribution pattern of AGS proteins in the central nervous system

\begin{tabular}{|c|c|c|c|c|c|}
\hline Brain regions & AGS1 & AGS2 & AGS3 & AGS5 & AGS6 \\
\hline Amygdale & & & 78 & 78 & \\
\hline Cerebellum & & & 78 & 78 & 108 \\
\hline Cerebral cortex & 100 & 89 & 78 & 78 & 108,109 \\
\hline Corpus callosum & 100 & & & & \\
\hline Dorsal root ganglia & & & & & 109 \\
\hline Forebrain & & & & & 109 \\
\hline Globus pallidus & & & & & 108 \\
\hline Hippocampus & 100 & $85,103-105$ & 56,78 & $56,57,78$ & 108 \\
\hline Hypothalamus & & & 78 & 78 & \\
\hline Inferior colliculus & & & & & 108 \\
\hline Lateral ventricles & & 103,104 & & & \\
\hline Medulla & & & 78 & 78 & \\
\hline Midbrain & & & & & 108 \\
\hline Nucleus accumbens core & & & $31-33$ & & \\
\hline Neural tube & & & & & 109 \\
\hline Olfactory bulb & & & 78 & 78 & \\
\hline Prefrontal cortex & 101 & & 31,78 & 78 & \\
\hline Retinal ganglion cell & 98 & & & & \\
\hline Sciatic nerve & & 106 & & & \\
\hline Spinal cord & 102 & 106 & & 59 & \\
\hline Striatum & & & 78 & 78 & 108 \\
\hline Substantia nigra & & & 78 & 78 & 108 \\
\hline Thalamus & & & 78 & 78 & 108,109 \\
\hline Third ventricles & & 103 & & & \\
\hline Ventral tegmental area & & & 78 & 78 & \\
\hline Ventricular zone & & & & 107 & \\
\hline
\end{tabular}

Figures denote references.

teine 11 [17] and is associated with elevated GTP binding on AGS1 as well as GEF activity [14]. The nNOS-mediated activation of AGS1 is hugely enhanced by the co-transfection of CAPON. In contrast, the GEF activity of AGS1 is reduced in $\mathrm{nNOS}^{-/-}$mice [14]. Since the NMDA receptor stimulates nNOS activation [18], it has been suggested that AGS1 is activated by NMDA receptor-mediated NO synthesis with CAPON as an adaptor protein that brings AGS1 and nNOS into juxtaposition (fig. 1). Subsequently, the activated AGS1 facilitates guanine nucleotide exchange on $G \alpha_{i}[14]$ and regulates expression of immediate-early genes, such as c-Fos, JunB and EGR-1, as well as CRE-dependent transcription via MAPK pathway [19] (fig. 1, 2).

AGS1 has been identified as a circadian rhythm related gene with its expression in the SCN altering in a circadian rhythmic manner [13]. The expression of ags 1 in thalamus, piriform cortex and hippocampus, however, is not rhythmic. The AGS1 gene expression in SCN is minimized and maximized at zeitgeber time (ZT) 2 and 14 , respectively, with approximately five-fold difference. In cryptochrome1 (cry1) and cryptochrome2 (cry2) double knock-out mice, the rhythmic gene expression of AGS1 is abolished [13]. These observations suggest the involvement of AGS1 in circadian rhythm.

The generation of dexrasl ${ }^{-/-}$mice [15] has revealed a role of AGS1 in gating the photic and non-photic stimuli for circadian entrainment. The photic phase response curve indicates dexras1 ${ }^{-/}$mice have robust phase advances in the middle of the daytime (ZT8) and at late subjective night (ZT20) in response to the light pulses, whereas the wild-type mice do not [16]. The dexras1 ${ }^{-/}$mice cannot induce phase delays in response to light at early subjective night (ZT14) $[15,16]$, and they also exhibit increased sensitivity to non-photic stimuli as compared to the wildtype [15]. The normal regulation of external stimuli entrainment in dexras1 ${ }^{-/-}$mice is completely disrupted and has responses opposite to the wild-type. 
Fig. 1. Putative photic and nonphotic pathways of the circadian clock. In the photic pathway, light stimuli act through the NMDA receptors in the SCN and activate AGS1. The activated AGS1 facilitates exchange of GDP for GTP on $\mathrm{G}_{\mathrm{i}}$ via its GEF activity leading to the regulation of a set of clock genes for circadian clock control. In the nonphotic pathway, the nonphotic stimuli are mediated by the NPY receptor in the SCN. The nonphotic pathway is inhibited by the photic pathway through AGS1 which competes against the NPY receptor for a common pool of $\mathrm{G} \alpha_{\mathrm{i}}$-GDP. Arrow with solid line = activation; arrow with dotted line = activation through intermediates; two arrows pointing to opposite directions $=$ competition .

Fig. 2. A proposed model of photic responsiveness regulation of the circadian clock at different ZT by AGS1. At ZT8, the lightinduced phase advance in dexras $1^{-/-}$mice indicates the importance of AGS1 gating the light input to the circadian clock. The effect of AGS1 is mediated by MAPK pathway inhibition but the exact mechanism remains unclear. At ZT14, photic stimuli activate AGS1 via the NMDA receptor and modulate clock genes expression in a MAPK-dependent pathway. At ZT20, the light responsiveness of the circadian clock is regulated by $\mathrm{PAC1}$ receptor. The activation of PAC1 receptor releases $\mathrm{G}_{\mathrm{s}}$ and $\mathrm{G} \beta \gamma$, which stimulate adenylyl cyclases and increase cAMP level. The PAC1-mediated pathway is considered to be inhibited by the light-induced $\mathrm{G}_{\mathrm{i}}$-GTP via AGS1.
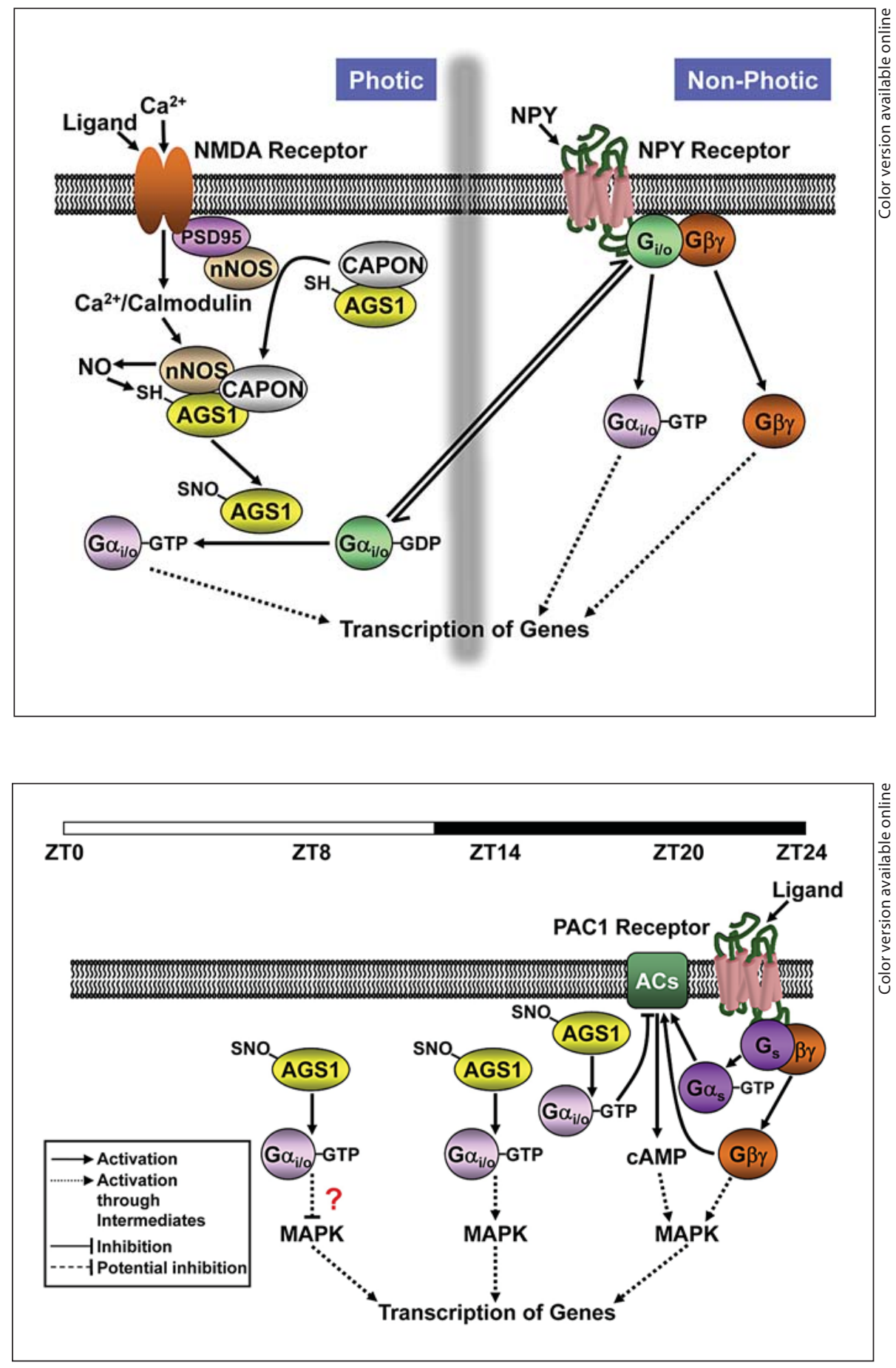

The differently modulated MAPK/ERK pathway in the dexrasl ${ }^{-/}$mice at different ZT is considered as the cause of altered sensitivity of the circadian clock to light. At ZT14, light-induced ERK activation in the SCN is attenuated in the dexras1 ${ }^{-/-}$mice [15], whereas at late ZT20 a significantly higher ERK phosphorylation level than the wild-type in response to light exposure is noted [16]. Moreover, light-induced phosphorylated ERK level at ZT8 is increased in dexras1 ${ }^{-/-}$mice but not in wild-type mice [16]. To sum up, AGS1 is responsible for enhancing 
the light-induced ERK phosphorylation at ZT14 and, conversely, suppresses the activation of ERK at ZT8 and ZT20 in the wild-type mice. This observation can be linked to the rhythmically expressed AGS1 in SCN. The AGS1 level in SCN is maximal at ZT14 but is relatively low at ZT8 and ZT20 [13].

Although the responsiveness of the circadian clock to light is also influenced by other rhythmically expressed proteins, such as the NMDA receptor channel subunits epsilon 3 and zeta 1 [20], the expression profile of AGS1 plays a major part in gating the light input to the circadian clock. How does altering the expression level of AGS1 generate different responses to light? This is one of the key questions to unlock the role of AGS1 in the control of circadian rhythm. The phase delay of the wild-type mice at ZT14 is presumably caused by the activation of NMDA receptors (fig. 2). Infusion of MEK1/2 inhibitor (U1026) inhibits the phase delay of both genotypes [15]. Interestingly, pertussis toxin (PTX) treatment significantly reduces the level of NMDA-induced phase shifting of wild-type animals to the level of dexrasl ${ }^{-/-}$mice, while having no effect on dexras1 ${ }^{-/-}$mice [15]. It implies that $\mathrm{G} \alpha_{\mathrm{i} / \mathrm{o}}$ signaling is involved in the photic entrainment at ZT14 and is perhaps modulated by the GEF activity of AGS1. It has also been suggested that light exposure at ZT14 stimulates the NMDA receptor and activates AGS1 by S-nitrosylation via the nNOS/CAPON/AGS1 complex [14] (fig. 1). Activated AGS1 may then facilitate the exchange of GDP for GTP on G $\alpha_{i}$ proteins and induce downstream signals, including the MAPK pathway. The activated MAPK pathway in turn modulates the behavioral phase shifts and transcription of genes [19].

The responses of circadian clock to light at ZT20 are regulated by $\mathrm{G}_{\mathrm{s}}$-linked pituitary adenylate cyclase-activating polypeptide (PACAP) type I receptor (PAC1) [16, 21] (fig. 2). PACAP 6-38, a potent antagonist of PAC, and U0126 block the phase advances [16]. Overexpression of AGS1 or a G $\beta \gamma$ scavenger, the C-terminus of $\beta$-adrenergic receptor kinase ( $\beta A R K-c t)$, reduces the PACAP-induced Elk1 transactivation by over $55 \%$, as compared to the control [16]. In addition, dexras1 ${ }^{-/-}$mice have higher cAMP basal levels at ZT20 as compared to the wild-type mice, and photic stimuli can further stimulate the cAMP production in $\operatorname{dexras}^{-/-}$mice [16]. It has been hypothesized that the stimulation of NMDA receptor by light activates AGS1 and promotes the formation of $\mathrm{G \alpha}_{\mathrm{i}}$-GTP which may subsequently inhibit $\mathrm{G}_{\mathrm{s}}$-coupled pathways [16].

The mechanism of the light-induced phase advance in the dexras1 ${ }^{-1-}$ mice at ZT8 remains unclear [16]. The phase advance can be abolished by U0126 infusion indicating that the phase shift is mediated by an ERK-dependent pathway [16]. As nocturnal rodents do not respond to photic stimuli during daytime at both behavioral and cellular levels [22], the light-induced phase advance at ZT8 in the dexras1 ${ }^{-1-}$ mice further confirms the importance of AGS1 in gating the light input to the circadian clock. Successful identification of interacting partners of AGS1 at ZT8 might explain how AGS1 controls the sensitivity of the circadian rhythm to light at daytime in rodents.

The regulation of nonphotic stimuli by AGS1 has been unmasked by studying the antagonistic effect of neuropeptide Y (NPY), a neurotransmitter involved in nonphotic-like effects [23], on NMDA-induced phase shifts. The NMDA-mediated phase shift in dexras $1^{-/-}$mice SCN neurons are more sensitive to NPY antagonistic effect than wild-type mice, and such effect can be reverted by PTX treatment [14]. The inhibitory effect of AGS1 on NPY receptor-mediated signaling is possibly caused by AGS1 competing for a common pool of $G \alpha_{i-}$ GDP against NPY receptor [15], and it may apply to other $\mathrm{G} \alpha_{\mathrm{i}}$-mediated signaling with a mechanism depicted in figure 1.

Since AGS1 activates $G \alpha_{i}$, it may affect $G_{i}$-coupled receptors which play a role in circadian rhythm. For instance, melatonin $\mathrm{MT}_{1}$ and $\mathrm{MT}_{2}$ receptors [24] are potential targets of AGS1. Other circadian rhythm-related $\mathrm{G}_{\mathrm{i}^{-}}$ coupled receptors include 5-hydroxytryptamine $\left(5-\mathrm{HT}_{1 \mathrm{~B}}\right.$ and 5- $\left.\mathrm{HT}_{5 \mathrm{~A}}\right)[25,26]$, dopamine $\left(\mathrm{D}_{2}\right.$ and $\left.\mathrm{D}_{3}\right)$ [27], GABA $\left(\mathrm{GABA}_{\mathrm{B}}\right)$ [28], prokineticin 2 [29] and prostanoid $\mathrm{EP}_{1}$ [30] receptors. Although not all of these receptors are expressed in the SCN, they are co-expressed with AGS1 in one or more regions of the nervous system and therefore may be regulated by AGS1. If so, AGS1 may also participate in diseases involving these receptors, such as Parkinson's disease, Alzheimer's disease and schizophrenia.

\section{Development and Maintenance of Drug Addiction by AGS3}

AGS3 has been reported as a protein involved in multiple processes including addiction [31-34], aggresomal pathway [35], asymmetric cell division [36], cardiovascular function [37], cell proliferation [38], macroautophagy [39], membrane protein trafficking [40] and metabolism [37]. Among these biological adaptations, the roles of AGS3 in the CNS regulating drug addiction and asymmetric cell division are discussed in this review. AGS3 is broadly distributed in the CNS, with its function remain- 


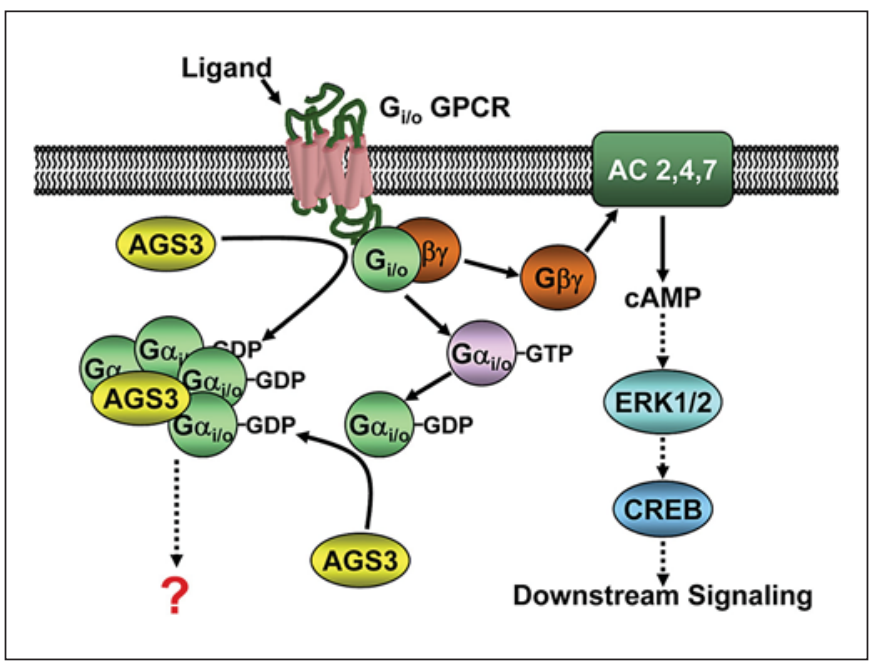

Fig. 3. Effects of AGS3 on GPCR signaling. AGS3 actively binds and stabilizes trimeric $\mathrm{G}_{\mathrm{i}}$-GDP leading to the dissociation of G $\beta \gamma$ for downstream signaling. The recycling of $\mathrm{G} \alpha_{\mathrm{i}}-\mathrm{GDP}$ is suppressed by AGS3 in the form of AGS3/G $\alpha_{\mathrm{i}}$-GDP complex, and the AGS3/G $\alpha_{\mathrm{i}}$-GDP complex is a potential signaling molecule for signal transduction. Arrow with solid line = activation; arrow with dotted line $=$ activation through intermediates .

ing unknown in most of the brain regions. It is a GDI which actively competes against $\mathrm{G} \beta \gamma$ subunits for $\mathrm{G}_{\mathrm{i}^{-}}$ GDP subunit $[5,41]$. AGS3 can actively uncouple $\mathrm{G} \alpha_{\mathrm{i}^{-}}$ GDP subunits from $\mathrm{G}_{\mathrm{i}}$-coupled receptors [41] and presumably leads to attenuation of $\mathrm{G} \alpha_{\mathrm{i}}$ signaling and augmentation of G $\beta \gamma$ signaling as illustrated in figure 3.

Drug addiction is a neuropathological disorder caused by the repeated administration of drugs. The mechanisms of its development remain unclear, and may vary for different drugs. In recent studies, AGS3 expression level has been found to be up-regulated in the prefrontal cortex (PFC) and/or nucleus accumbens core (NAcore) in response to cocaine withdrawal [31]. This finding has spurred a new inspiration to understand drug addiction, with the idea that AGS3 may represent a core component in the development of drug addiction. The AGS3 protein level is increased in certain animal models of drug addiction. In cocaine relapse, AGS3 is upregulated in rat NAcore and PFC 3 weeks after cocaine withdrawal and remains so for 8 weeks [31]. In ethanol addiction, AGS3 is up-regulated in NAcore 3 weeks after abstinence without any change of AGS3 level in other nuclei related to the rewarding systems (e.g. PFC and dorsal striatum) [32]. Similar AGS3 up-regulation is also reported in NAcore/ striatal neurons after $5 \mathrm{~h}$ abstinence of chronic morphine treatment [33]. Although there is no report on chronic heroin administration upregulating AGS3 in the brain regions, knock-down of AGS3 has been shown to eliminate heroin-seeking behavior in rats [34].

The AGS3 expression profile has been considered as a control switch in drug addiction; however, there is no indication as to how AGS3 expression level is regulated. AGS3 is found to be coregulated with USP9x (ubiquitin specific protease $9 \mathrm{x}$ ) in the rat PFC after cocaine withdrawal [42]. USP9x interacts with the GPR motifs of AGS3 and stabilizes AGS3 by de-ubiquitination. Therefore, up-regulation of USP9x results in an augmentation of AGS3 protein level. But is it the same case for other opiates and addictive drugs? Is AGS3 expression profile a common molecular determinant for the development of other addictions, such as nicotine addiction?

On the other hand, the activation of G $\beta \gamma$ signaling by up-regulated AGS3 can regulate a series of transcription factors, such as members of the STAT family. This hypothesis correlates with our recent demonstration that several $\mathrm{G} \beta \gamma$ subunits containing the neuronal-specific $\mathrm{G} \gamma_{2}, \mathrm{G} \gamma_{4}$, $\mathrm{G} \gamma_{7}$ and $\mathrm{G} \gamma_{9}$ can induce phosphorylation of STAT1 and

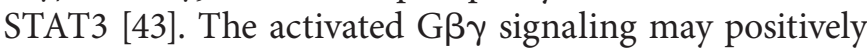
feedback to enhance the production of AGS3 by inducing transcription via STAT1/STAT3, although the existence of transcription factor-binding sites for STAT1/STAT3 on the AGS3 promoter sequence is yet to be studied. Therefore, the expression level of AGS3 is possibly controlled at both transcription and post-translational levels.

There are a number of reports describing altered $G$ protein kinetics and stoichiometry in cocaine [44], heroin [45], and alcohol [46] addiction models. It is therefore of particular interest to study the role of AGS3 in different addiction models. The $\mathrm{G} \alpha_{\mathrm{i}}$ signaling is reduced in PFC upon AGS3 upregulation during cocaine abstinence [31]. In contrast, AGS3 knock-down recovers the altered $\mathrm{G} \alpha_{\mathrm{i}}$ signaling and stops drug seeking behavior [31]. There is no direct evidence, thus far, to demonstrate that up-regulated AGS3 can modulate $G \alpha_{i}$ or $G \beta \gamma$ signaling in other addiction models (e.g., heroin and ethanol). However, the sequestration of G $\beta \gamma$ subunit by $\beta A R K 1$ has been shown to have the same effect as the knock-down of AGS3 for both heroin [34] and ethanol [32] addictions, suggesting that AGS3 and G $\beta \gamma$ may exist in the same signaling pathway and the G $\beta \gamma$-mediated signaling could be enhanced by the up-regulated AGS3 via stabilization of $G \alpha$-GDP.

Some downstream effectors of G $\beta \gamma$ subunits such as adenylyl cyclases (ACs) 2 and 4 have been reported to be required in $\mu$-opioid receptor (MOR) signaling. The knock-down of AC2 or AC4 abolishes the MOR-mediat- 


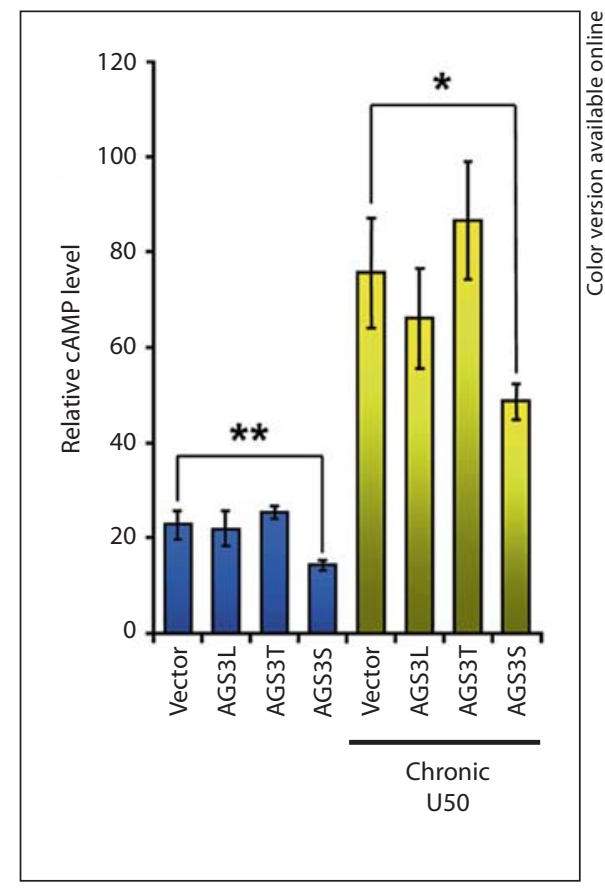

Fig. 4. The GPR domain of AGS3 reduces intracellular cAMP formation. HEK293 cells stably expressing the $\kappa$-opioid receptor KOR were transfected with vector, full length AGS3, AGS3 truncated mutant containing the seven TPR motifs (AGS3T) or AGS3 splice variant containing three of the GPR motifs (AGS3S). Cells were incubated with vehicle or KOR agonist U50 (10 nM) and $\left[{ }^{3} \mathrm{H}\right]$ adenine overnight and treated with forskolin $(10 \mu \mathrm{M})$ for $30 \mathrm{~min}$ before cell lysis. The lysates were applied to column chromatography for ATP, ADP and cAMP isolation, and the different eluates were subjected to scintillation counting. Relative cAMP level was calculated by normalizing the $\left[{ }^{3} \mathrm{H}\right] \mathrm{cAMP}$ level to total $\left[{ }^{3} \mathrm{H}\right]$ level. Detailed cAMP accumulation assay procedure is described in [110]. ${ }^{*} \mathrm{p}<0.05 ;{ }^{* *} \mathrm{p}<0.01$. All data presented are representative of three experiments, and individual values were the average of triplicate.

ed PKA activation [34]. Interestingly, AC super-activaton induced by morphine withdrawal does not require $G \beta \gamma$ function because $\beta A R K 1$ has no effect on it [33]. Moreover, the CAMP super-activation by morphine withdrawal requires AGS3, AC5 and AC7 [33] but not AC2 or AC4. These observations further demonstrate that AGS3 is required in the development of different types of drug addiction. However, the signaling pathways involved appear to be different. We have previously demonstrated that multiple $G$ proteins and signaling components participate in opioid receptor-mediated AC super-activation [47-52], and our recent focus is on the effect of AGS3 on К-opioid-induced AC super-activation. Overexpression of full length or the GPR motif of AGS3 is unable to mim-

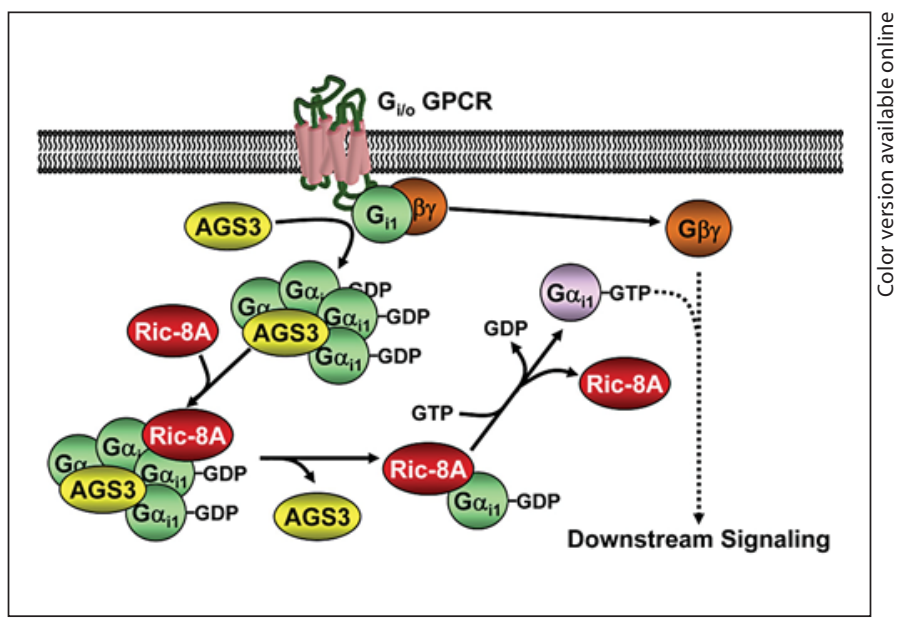

Fig. 5. Ric- $8 \mathrm{~A}$ activates $\mathrm{G} \alpha_{\mathrm{i} 1}$ in the $\mathrm{AGS} 3 / \mathrm{G} \alpha_{\mathrm{i} 1}$-GDP complex. AGS3 actively competes against G $\beta \gamma$ for trimeric $\mathrm{G}_{\mathrm{i}^{-}} \mathrm{GDP}$ to form the AGS3/G $\alpha_{i 1}$-GDP complex. The freed G $\beta \gamma$ can regulate gene transcription via various $G \beta \gamma$-responsive effectors. Despite binding to AGS3, G $\alpha_{i 1}$-GDP remains as a viable substrate of Ric-8A and can be converted to its GTP-bound active form. The activated $\mathrm{G}_{\mathrm{i} 1}$ is released from Ric-8A for downstream signaling. Arrow with solid line $=$ activation; arrow with dotted line $=$ activation through intermediates.

ick or enhance the AC super-activation in HEK293. In contrast, our data suggests that the GPR motif of AGS3 reduces the $\kappa$-opioid receptor-mediated AC super-activation (fig. 4). This is supported by previous literature wherein AGS3S inhibits the sensitization of $\mathrm{G}_{\mathrm{s}}$-mediated AC signals in $\mathrm{CHO}$ cells [53]. The differences among these observations could be explained by the different complements of $\mathrm{G}$ protein subunits and/or AC isoforms present in the various cellular models.

The majority of studies on AGS3 signaling have been focused on the enhancement of $G \beta \gamma$ signaling and the inhibition of $\mathrm{G} \alpha_{i}$ subunit recycling, and there is little information regarding the potential biological function of the AGS3/G $\alpha_{\mathrm{i}^{-}}$GDP complex. Is the complex a signaling molecule rather than merely inhibiting the $\mathrm{G} \alpha_{\mathrm{i}}$ signaling? The AGS3/G $\alpha_{i 1}$-GDP complex has been shown to be in close proximity with Ric-8A, a GEF which facilitates the exchange of GDP to GTP on G $\alpha_{i 1}$ [54] (fig. 5). Another study has demonstrated that Ric-8A can promote the exchange of GDP for GTP on G $\alpha_{i}$ subunit bound to AGS3 in Caenorhabditis elegans [55]. These observations present a mechanism contrary to the common understanding of AGS3 inhibiting the $G \alpha_{i}$ signaling and enhancing the G $\beta \gamma$ signaling. Further study is required to understand the characteristics of the AGS3/G $\alpha_{i}-$ GDP complex. 
The development of addiction requires long-term neuro-adaptations in relevant brain circuits. AGS3 has been described to alter the trafficking of protein [40], a crucial component of synaptic plasticity, including plasma membrane receptors and channels. The Drosophila melanogaster partner of inscuteable (mPins), an AGS3 homolog, has been reported to enhance trafficking of SAP102 and NMDA receptor to the plasma membrane in neurons [56]. Furthermore, the overexpression of AGS3 in COS7 cells modulates the surface expression level of a set of heterologously expressed plasma membrane receptors and channels with a significant increase in surface expression of inwardly rectifying potassium ion channel subtype Kir2.1 [40]. Identifying plasma membrane receptors or channels regulated by AGS3 in neurons would be one of the key tasks in future studies.

\section{Regulation of Asymmetric Cell Division by AGS3 and AGS5}

Asymmetric cell division is a biological process which divides the mother cell into two daughter cells with different cell fates. It involves three main steps: establishment of cell polarity, mitotic spindle orientation, and cell fate determinants segregation, each of which requires tight regulation in order to properly divide the cell asymmetrically. Asymmetric cell division plays an important role in developing brain by regulating neural progenitor cells to produce one daughter cell capable to differentiate into the many cell types of the CNS and another daughter cell for self-renewal. Therefore, significant efforts have been put into the study of mechanisms of asymmetric cell division in the past decade in order to broaden our understanding in brain development and develop therapeutic approaches to target cancer stem cell. To date, abundant literatures indicate that the GPR-containing AGS3 and AGS5 are involved in asymmetric cell division.

AGS5 is a close homologue of AGS3. It contains seven TPR, four GPR domains, and shares $66 \%$ homology with AGS3. Like AGS3, AGS5 is a GDI which can bind and sta-

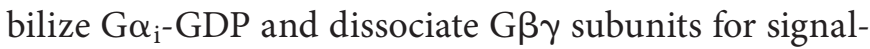
ing. AGS5 is also named as Leu-Gly-Asn-enriched protein (LGN) or GPSM2 named by HUGO Gene Nomenclature Committee. Apart from asymmetric cell division, AGS5 plays various roles in multiple biological functions including GIRK channel regulation [57], mitotic spindle organization [58-60], NMDA receptor trafficking [56] and phototransduction [61].
In Drosophila neuroblasts, a model for studying asymmetric cell division, the establishment of cell polarity along an apical-basal axis is tightly controlled by an evolutionarily conserved Par complex including Bazooka (Baz, a Drosophila homolog of Par3), Par6 and atypical PKC, localized at the apical cortex [62]. The Baz/Par6/ aPKC complex is responsible for establishing cell polarity and subsequently links with another protein complex consisting of Partner of Inscuteable (Pins; a Drosophila homolog of AGS3 and AGS5), Mud (nuclear mitotic apparatus, NuMA, in mammals) and $\mathrm{G} \alpha_{i}$ via Inscuteable (Insc) [63]. The Mud/Pins/G $\alpha_{\mathrm{i}}$ complex orientates mitotic spindles along the apical-basal axis of the neuroblasts $[64,65]$. These complex proteins are evolutionally conserved in mammals and are predicted to provide similar functions in mammalian asymmetric cell division.

Based on our current knowledge of asymmetric cell division obtained from D. melanogaster and C. elegans, it is considered that the evolutionarily conserved mammalian complexes of Par3/Par6/aPKC and NuMA/AGS5/ $\mathrm{G} \alpha_{\mathrm{i}}$ are physically linked by the adaptor protein mInsc. However, a recent publication shows that the interactions of NuMA and mInsc with AGS5 are mutually exclusive with AGS5 binding to mInsc preferentially [66]. Therefore, it has been suggested that the Baz/Par6/aPKC/Insc complex recruits Pins to the apical cortex at the delamination/late interphase and subsequently free the Pins for forming the Mud/Pins $/ \mathrm{G} \alpha_{\mathrm{i}}$ complex at the prometaphase [66]. This observation renews our understanding of the roles of these two complexes in asymmetric cell division.

Increasing evidence shows that AGS3 is involved in asymmetric cell division. In cerebral cortical progenitor cells from developing mammalian neocortex, AGS3 regulates the apical-basal division and asymmetric cell-fate decisions via G $\beta \gamma$ subunits [36]. Knock-down of AGS3 shifts the mitotic spindle from the apical-basal axis to the planar axis and leads to failures in proper mitotic spindle orientation and asymmetric cell-fate determination [36]. The impairment of the G $\beta \gamma$ signaling causes the same defects as AGS3 knock-down, suggesting that AGS3 and the $G \beta \gamma$ subunits exist in the same pathway and that AGS3 may regulate the G $\beta \gamma$ signaling via its GDI activity [36]. Moreover, the GPR domains of AGS3 can be phosphorylated by LKB1, a serine/threonine kinase which is involved in the regulation of cell polarity and cell cycle progression [67]. Although the biological significance of AGS3 phosphorylation by LKB1 remains unknown, it seems to diminish GDI activity in vitro [67]. In addition, AGS3 interacts with mammalian Insc (mInsc) 
and form a complex with Par3 [68, 69], implying a potential role in the regulation of spindle orientation and cell fate in the developing retina [68].

AGS5 has been extensively reported to play a key regulatory role in asymmetric cell division by controlling mitotic spindle orientation and organization in the neuroepithelium [59], epidermis [70], retina [68], dermomyotome [71], and distal epithelium of embryonic lung [72], as well as controlling meiotic spindle orientation in mouse oocytes [73]. Ectopic expression or knock-down of AGS5 results in disruption of spindle-pole organization, chromosome segregation and cell cycle progression [74, 75]. AGS5 interacts with NuMA via its N-terminal domain $[74,76]$ and regulates the NuMA dynamics at the mitotic spindle poles [77]. The interaction between AGS5 and $\mathrm{NuMa}$ is essential to the assembly and organization of the mitotic spindle during mitosis [74, 76]. In addition, the interaction between AGS5 and $\mathrm{G} \alpha_{\mathrm{i}}$ leads to a cortical repositioning of the mitotic spindle poles at metaphase closer to the cell cortex [58].

AGS3 and AGS5 share similar motif structures and both interact with $G \alpha_{i}$ proteins, they nevertheless act differently in different cellular systems. They differ in their tissue distribution pattern, expression profile and subcellular localization. As shown in table 2, they show similar distribution pattern in the brain [78], but they are differentially regulated during brain development. Maximum expression of AGS3 occurs on postnatal day 7 and is significantly decreased by day 22 in the brainstem, cerebellum, cortex, hippocampus and midbrain [78]. In contrast, the expression level of AGS5 in the same brain regions, except midbrain, is increased overtime during postnatal days 1-22 [78]. Furthermore, AGS3 and AGS5 appear to have different cell type specificities. AGS3 is primarily expressed in neurons whereas AGS5 is found in neurons, astroglia and microglia [78]. The subcellular localization of AGS3 and AGS5 is found to be different in different cell types [78, 79]. In the progenitor cells, AGS5 shows asymmetric distribution in a cell cycle-dependent manner, while AGS3 has a diffused cytoplasmic distribution [79]. These observations imply that one or more unidentified domains in AGS3 and AGS5 may confer their differential regulations in various cell types and developmental stages. How asymmetric cell division is regulated by AGS3 and AGS5 in mammalian brains remains a major area of investigation. As AGS3 is primarily expressed in neurons with maximum expression level in the brain at postnatal day 7 [78], it may play a more important role in early brain development for generating cell type diversities.

Neuronal Functions of AGS Proteins
It has been reported that $\mathrm{G} \alpha_{\mathrm{i}}$ is responsible for recruiting AGS5 to the cell cortex $[60,76]$. However, it seems that the AGS5/G $\alpha_{i}$ interaction does more than just the localization of AGS5. The value of GDI activity of AGS3/5 in asymmetric cell division has been addressed in mammalian cortical progenitor cells where AGS3 is a potential regulator of the $G \beta \gamma$ signaling in regulating spindle orientation and cell-fate determination [36]. Another function of AGS3/5/G $\alpha_{\mathrm{i}}$-GDP is to act as a substrate of Ric- $8 \mathrm{~A}$, a GEF which promotes the exchange of GDP for GTP on $\mathrm{G} \alpha_{\mathrm{i}}$. It recognizes and interacts with the free $\mathrm{G} \alpha_{\mathrm{i}}$-GDP subunit but not with the $\mathrm{G}_{\mathrm{i}^{-}} \mathrm{GDP} / \mathrm{G} \beta \gamma$ heterotrimeric complex [80]. Ric-8A also catalyzes guanine nucleotide exchange on $G \alpha_{i 1}$-GDP bound to AGS3 [54] or in the $\mathrm{NuMA} / \mathrm{AGS} 5 / \mathrm{G} \alpha_{\mathrm{i}}$ complex which is responsible for regulating mitotic spindle orientation $[60,81]$. The release of $\mathrm{G} \alpha_{\mathrm{i}}-\mathrm{GTP}$ from the NuMA/AGS5/G $\alpha_{\mathrm{i}}$ complex leads to the dissociation of NuMA for capturing dynein/dynactin complexes at the cell cortex adjacent to the spindle poles and subsequently tethering microtubules for spindle poles assembly and organization [60]. Further studies are needed to delineate the roles of $\mathrm{AGS} 3 / 5 / \mathrm{G} \alpha_{\mathrm{i}^{-}} \mathrm{GDP}$ in asymmetric cell division.

\section{Control of Neurite Outgrowth by AGS2 and AGS6}

Neurite outgrowth is a tightly regulated function in developing neurons, essential for the formation of axons and dendrites. It involves the change of tubulin and actin cytoskeleton dynamics at the growth cone for elongation and branching of the neurites. A decrease in the number of neurite outgrowths is a hallmark of neuronal diseases such as Alzheimer's disease. Increasing evidence has suggested that AGS2 and AGS6 are involved in the regulation of neurite outgrowth.

AGS2 is a light chain component of the cytoplasmic dynein motor protein complex and is also known as Tcomplex testis-specific protein 1 (Tctex-1) or dynein light chain Tctex-type 1 (DYNLT1). It directly interacts with

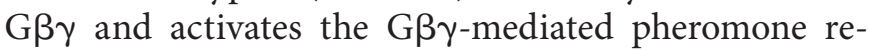
sponse pathway in S. cerevisiae [2]. Apart from its function in anterograde and retrograde trafficking [82], it is involved in a number of diversified biological functions including bone resorption [83], cilium length control [84], neurite outgrowth [85-87], regulation of the fate of neural progenitors [88], cortical neurogenesis [89] and Orexin receptor signaling [90]. The protein expression of AGS2 within the CNS (table 2) implicates its involvement in neuronal functions. 
A role of AGS2 in neurite outgrowth has been unveiled recently. AGS2 knock-down in hippocampal neurons causes neurite development failure, whereas ectopic expression of AGS2 promotes multiple abnormally long axon-like neurites [85]. The neurite outgrowth is regulated by AGS2 in a dynein-independent manner as demonstrated by AGS2-T94E, a mutant unable to bind dynein intermediate chain and predictably do not incorporate into dynein complex [85]. Neurons ectopically expressing AGS2T94E appear to have similar axon-like neurites as observed in the wild-type transfectants [85]. This observation has led to the study of subcellular distribution pattern of AGS2 in neurons. It was found that AGS2 can exist in either dynein-associated or dynein-free pool depending on its interaction with $G \beta \gamma$, which competes against dynein intermediate chain for AGS2 binding and regulates the dynamics of the dynein-free pool of AGS2 [86]. Inhibition of G $\beta \gamma$ signaling by $\beta A R K-c t$ inhibits neurite outgrowth, suggesting that G $\beta \gamma / A G S 2$ complex is essential for AGS2mediated neuritogenesis [86]. However, the mechanism underlying the regulation of neurite outgrowth by $G \beta \gamma /$ AGS2 complex remains unclear. Investigation into the modulation of G $\beta \gamma$ downstream signaling by AGS2 may further reveal the mechanism underlying the control of neurite outgrowth. In addition, the opposite roles of Rac1 and RhoA on promoting and inhibiting neurite outgrowth [91], respectively, are regulated by AGS2 [85, 87].

AGS6, also known as RGS12, is a multidomain protein which contains functionally diverse domains including GPR, PDZ, PTB domain, regulator of G protein signaling (RGS) domain and Ras binding domain (RBD). AGS6 may act as a GDI or a GTPase-activating protein (GAP) due to the existence of the GPR and RGS domains, respectively. AGS6 has widespread expression in the CNS (table 2). It has been reported that AGS6 is involved in neuronal differentiation [92], terminal differentiation of osteoclasts [93], regulation of calcium channels [94, 95], PDGF $\beta$ receptor signaling [96] and Ras signaling [92]. Recently, it has been demonstrated that AGS6 is involved AGS6 in PC12 cells as well as dorsal root ganglia neurons via a Ras-dependent signal [92]. decade and a number of neuronal functions have been demonstrated to be regulated by them. A pressing ques- tion is how AGS proteins achieve so many regulatory roles in the CNS? This is probably achieved by specific cellular proteome in each distinct brain region leading to different regulations by the AGS proteins. The different effects of AGS1 on circadian rhythm at different ZTs are examples of how protein expression patterns trigger distinct functional roles. Asymmetric cell division and neuritogenesis are major events in brain development; it has been suggested that AGS proteins may play important regulatory roles during brain development. Therefore, it is of particular interest to extend the studies of AGS proteins in neurogenesis. Moreover, despite the demonstration that AGS proteins can activate the S. cerevisiae pheromone response pathway in the absence of a pheromoneresponsive GPCR, the precise mechanism by which AGS proteins modulate $G$ protein signaling in mammalian cells remain poorly defined. The ability of AGS proteins to elicit $G \beta \gamma$-dependent signaling is mostly inferred from its binding preference for GDP-bound $\mathrm{G} \alpha_{\mathrm{i}}$ subunits. As illustrated by their participation in complex adaptive responses such as drug addiction, the AGS proteins are likely to affect more than just the G $\beta \gamma$ signaling pathway. A thorough understanding of how the expression and localization of AGS proteins are regulated in neurons will help to discern their function in our CNS. The delineation of the mechanisms underlying each AGS-mediated neuronal function in mammalian system will be extremely challenging.

\section{Acknowledgements}

We thank Joy Chan for critical reading of the manuscript. This work was supported in part by grants from the Research Grants Council of Hong Kong (HKUST 661807), the University Grants Committee (AoE/B-15/01), and the Hong Kong Jockey Club. in regulating neurite outgrowth [92]. Knock-down of inhibits the nerve growth factor-mediated neuritogenesis

\section{Conclusion}

AGS proteins have been intensively studied in the past

References

\footnotetext{
1 Cismowski MJ, Takesono A, Ma C, Lizano JS, Xie X, Fuernkranz H, Lanier SM, Duzic E: Genetic screens in yeast to identify mammalian nonreceptor modulators of G-protein signaling. Nat Biotechnol 1999;17:878883.

-2 Takesono A, Cismowski MJ, Ribas C, Bernard M, Chung P, Hazard S, Duzic E, Lanier SM: Receptor-independent activators of heterotrimeric G-protein signaling pathways. J Biol Chem 1999;274:33202-33205.

- 3 Blumer JB, Cismowski MJ, Sato M, Lanier SM: AGS proteins: receptor-independent activators of G-protein signaling. Trends Pharmacol Sci 2005;26:470-476.
} 
4 Cismowski MJ, Ma C, Ribas C, Xie X, Spruyt M, Lizano JS, Lanier SM, Duzic E: Activation of heterotrimeric G-protein signaling by a ras-related protein. Implications for signal integration. J Biol Chem 2000;275:2342123424.

5 De Vries L, Fischer T, Tronchère H, Brothers GM, Strockbine B, Siderovski DP, Farquhar MG: Activator of $G$ protein signaling 3 is a guanine dissociation inhibitor for $\mathrm{G} \alpha_{\mathrm{i}}$ subunits. Proc Natl Acad Sci USA 2000;97: 14364-14369.

6 Sato M, Cismowski MJ, Toyota E, Smrcka AV, Lucchesi PA, Chilian WM, Lanier SM: Identification of a receptor-independent activator of G protein signaling (AGS8) in ischemic heart and its interaction with $\mathrm{G} \beta \gamma$. Proc Natl Acad Sci USA 2006;103:797-802.

7 Cismowski MJ: Non-receptor activators of heterotrimeric G-protein signaling (AGS proteins). Semin Cell Dev Biol 2006;17:334344.

-8 Blumer JB, Smrcka AV, Lanier SM: Mechanistic pathways and biological roles for receptor-independent activators of G-protein signaling. Pharmacol Ther 2007;113:488506.

9 Cheng HY, Obrietan K: Dexras1: shaping the responsiveness of the circadian clock. Semin Cell Dev Biol 2006;17:345-351.

$\rightarrow 10$ Bowers MS: Activators of G-protein signaling 3: a drug addiction molecular gateway. Behav Pharmacol 2010;21:500-513.

11 Blumer JB, Oner SS, Lanier SM: Group II activators of G-protein signalling and proteins containing a G-protein regulatory motif. Acta Physiol (Oxf) 2012;204:202-218.

12 Kemppainen RJ, Behrend EN: Dexamethasone rapidly induces a novel ras superfamily member-related gene in AtT-20 cells. J Biol Chem 1998;273:3129-3131.

13 Takahashi H, Umeda N, Tsutsumi Y, Fukumura R, Ohkaze H, Sujino M, van der Horst G, Yasui A, Inouye ST, Fujimori A, Ohhata T, Araki R, Abe M: Mouse dexamethasone-induced RAS protein 1 gene is expressed in a circadian rhythmic manner in the suprachiasmatic nucleus. Brain Res Mol Brain Res 2003;110:1-6.

14 Fang M, Jaffrey SR, Sawa A, Ye K, Luo X, Snyder SH: Dexras1:a G protein specifically coupled to neuronal nitric oxide synthase via CAPON. Neuron 2000;28:183-193.

$\checkmark 15$ Cheng HY, Obrietan K, Cain SW, Lee BY, Agostino PV, Joza NA, Harrington ME, Ralph MR, Penninger JM: Dexras1 potentiates photic and suppresses nonphotic responses of the circadian clock. Neuron 2004; 43:715-728.

16 Cheng HY, Dziema H, Papp J, Mathur DP, Koletar M, Ralph MR, Penninger JM, Obrietan K: The molecular gatekeeper Dexras1 sculpts the photic responsiveness of the mammalian circadian clock. J Neurosci 2006;26:12984-12995.
17 Jaffrey SR, Fang M, Snyder SH: Nitrosopeptide mapping: a novel methodology reveals S-nitrosylation of dexras1 on a single cysteine residue. Chem Biol 2002;9:1329-1335.

18 Bredt DS, Snyder SH: Nitric oxide mediates glutamate-linked enhancement of cGMP levels in the cerebellum. Proc Natl Acad Sci USA 1989;86:9030-9033.

19 Dziema H, Oatis B, Butcher GQ, Yates R, Hoyt KR, Obrietan K: The ERK/MAP kinase pathway couples light to immediate-early gene expression in the suprachiasmatic nucleus. Eur J Neurosci 2003;17:1617-1627.

20 Ishida N, Matsui M, Mitsui Y, Mishina M: Circadian expression of NMDA receptor mRNAs, epsilon 3 and zeta 1, in the suprachiasmatic nucleus of rat brain. Neurosci Lett 1994;166:211-215.

21 Chen D, Buchanan GF, Ding JM, Hannibal J, Gillette MU: Pituitary adenylyl cyclase-activating peptide: a pivotal modulator of glutamatergic regulation of the suprachiasmatic circadian clock. Proc Natl Acad Sci USA 1999;96:13468-13473.

22 Obrietan K, Impey S, Storm DR: Light and circadian rhythmicity regulate MAP kinase activation in the suprachiasmatic nuclei. Nat Neurosci 1998;1:693-700.

23 Lall GS, Biello SM: Neuropeptide Y, GABA and circadian phase shifts to photic stimuli. Neuroscience 2003;120:915-921.

24 Dubocovich ML, Hudson RL, Sumaya IC, Masana MI, Manna E: Effect of MT1 melatonin receptor deletion on melatonin-mediated phase shift of circadian rhythms in the C57BL/6 mouse. J Pineal Res 2005;39:113120.

25 Pickard GE, Weber ET, Scott PA, Riberdy AF, Rea MA: $5-\mathrm{HT}_{1 \mathrm{~B}}$ receptor agonists inhibit light-induced phase shifts of behavioral circadian rhythms and expression of the immediate-early gene c-fos in the suprachiasmatic nucleus. J Neurosci 1996;16:8208-8220.

26 Sprouse J, Reynolds L, Braselton J, Schmidt A: Serotonin-induced phase advances of SCN neuronal firing in vitro: a possible role for $5-\mathrm{HT}_{5 \mathrm{~A}}$ receptors? Synapse 2004;54:111118.

27 Imbesi M, Yildiz S, Dirim Arslan A, Sharma R, Manev H, Uz T: Dopamine receptor-mediated regulation of neuronal 'clock' gene expression. Neuroscience 2009; 158:537544.

28 Ralph MR, Menaker M: GABA regulation of circadian responses to light. I. Involvement of GABAA-benzodiazepine and $\mathrm{GABA}_{\mathrm{B}}$ receptors. J Neurosci 1989;9:2858-2865.

29 Cheng MY, Bullock CM, Li C, Lee AG, Bermak JC, Belluzzi J, Weaver DR, Leslie FM, Zhou QY: Prokineticin 2 transmits the behavioural circadian rhythm of the suprachiasmatic nucleus. Nature 2002;417:405410.

-30 Tsuchiya Y, Minami I, Kadotani H, Nishida E: Resetting of peripheral circadian clock by prostaglandin E2. EMBO Rep 2005;6:256261.
31 Bowers MS, McFarland K, Lake RW, Peterson YK, Lapish CC, Gregory ML, Lanier SM, Kalivas PW: Activator of G protein signaling 3:a gatekeeper of cocaine sensitization and drug seeking. Neuron 2004;42:269-281.

32 Bowers MS, Hopf FW, Chou JK, Guillory AM, Chang SJ, Janak PH, Bonci A, Diamond I: Nucleus accumbens AGS3 expression drives ethanol seeking through G $\beta \gamma$. Proc Natl Acad Sci USA 2008;105:12533-12538.

33 Fan P, Jiang Z, Diamond I, Yao L: Up-regulation of AGS3 during morphine withdrawal promotes CAMP superactivation via adenylyl cyclase 5 and 7 in rat nucleus accumbens/ striatal neurons. Mol Pharmacol 2009;76: 526-533.

34 Yao L, McFarland K, Fan P, Jiang Z, Inoue Y, Diamond I: Activator of $G$ protein signaling 3 regulates opiate activation of protein $\mathrm{ki}$ nase A signaling and relapse of heroin-seeking behavior. Proc Natl Acad Sci USA 2005; 102:8746-8751.

35 Vural A, Oner S, An N, Simon V, Ma D, Blumer JB, Lanier SM: Distribution of activator of G-protein signaling 3 within the aggresomal pathway: role of specific residues in the tetratricopeptide repeat domain and differential regulation by the AGS3 binding partners $\mathrm{G}_{\mathrm{i}} \alpha$ and mammalian inscuteable. Mol Cell Biol 2010;30:1528-1540.

- 36 Sanada K, Tsai LH: G protein $\beta \gamma$ subunits and AGS3 control spindle orientation and asymmetric cell fate of cerebral cortical progenitors. Cell 2005;122:119-131.

37 Blumer JB, Lord K, Saunders TL, Pacchioni A, Black C, Lazartigues E, Varner KJ, Gettys TW, Lanier SM: Activator of G protein signaling 3 null mice. I. Unexpected alterations in metabolic and cardiovascular function. Endocrinology 2008; 149:3842-3849.

38 Nadella R, Blumer JB, Jia G, et al: Activator of $\mathrm{G}$ protein signaling 3 promotes epithelial cell proliferation in PKD. J Am Soc Nephrol 2010;21:1275-1280.

39 Pattingre S, De Vries L, Bauvy C, Chantret I, Cluzeaud F, Ogier-Denis E, Vandewalle A, Codogno P: The G-protein regulator AGS3 controls an early event during macroautophagy in human intestinal HT-29 cells. J Biol Chem 2003;278:20995-21002.

40 Groves B, Gong Q, Xu Z, Huntsman C, Nguyen C, Li D, Ma D: A specific role of AGS3 in the surface expression of plasma membrane proteins. Proc Natl Acad Sci USA 2007;104:18103-18108.

$41 \mathrm{Ma} \mathrm{H}$, Peterson YK, Bernard ML, Lanier SM, Graber SG: Influence of cytosolic AGS3 on receptor- $\mathrm{G}$ protein coupling. Biochemistry 2003;42:8085-8093.

42 Xu Z, Xia B, Gong Q, Bailey J, Groves B, Radeke M, Wood SA, Szumlinski KK, Ma D: Identification of a deubiquitinating enzyme as a novel AGS3-interacting protein. PLoS One 2010;5:e9725. 
-43 Yuen JW, Poon LS, Chan AS, Yu FW, Lo RK, Wong YH: Activation of STAT3 by specific $\mathrm{G} \alpha$ subunits and multiple $\mathrm{G} \beta \gamma$ dimers. Int J Biochem Cell Biol 2010;42:1052-1059.

44 Xi ZX, Ramamoorthy S, Baker DA, Shen H, Samuvel DJ, Kalivas PW: Modulation of group II metabotropic glutamate receptor signaling by chronic cocaine. J Pharmacol Exp Ther 2002;303:608-615.

45 Kaplan GB, Sethi RK, McClelland EG, LeiteMorris KA: Regulation of G protein-mediated adenylyl cyclase in striatum and cortex of opiate-dependent and opiate withdrawing mice. Brain Res 1998;788:104-110.

-46 Waltman C, Levine MA, McCaul ME, Svikis DS, Wand GS: Enhanced expression of the inhibitory protein $\mathrm{G}_{\mathrm{i} 2} \alpha$ and decreased activity of adenylyl cyclase in lymphocytes of abstinent alcoholics. Alcohol Clin Exp Res 1993; 17:315-320.

-47 Tso PH, Wong YH: Deciphering the role of $\mathrm{G}_{\mathrm{i} 2}$ in opioid-induced adenylyl cyclase supersensitization. Neuroreport 2000;11: 3213-3217.

-48 Tso PH, Wong YH: $\mathrm{G}_{\mathrm{z}}$ can mediate the acute actions of $\mu$ - and $\kappa$-opioids but is not involved in opioid-induced adenylyl cyclase supersensitization. J Pharmacol Exp Ther 2000;295:168-176.

49 Tso PH, Yung LY, Wong YH: Regulation of adenylyl cyclase, ERK1/2, and CREB by $\mathrm{G}_{z}$ following acute and chronic activation of the delta-opioid receptor. J Neurochem 2000;74 1685-1693.

50 Tso PH, Wong YH: Opioid-induced adenylyl cyclase supersensitization in human embryonic kidney 293 cells requires pertussis toxin-sensitive $G$ proteins other than $G_{i 1}$ and $\mathrm{G}_{\mathrm{i} 3}$. Neurosci Lett 2001;299:25-28.

-51 Tso PH, Wong YH: Role of extracellular signal-regulated kinases in opioid-induced adenylyl cyclase superactivation in human embryonic kidney 293 cells. Neurosci Lett 2001; 316:13-16.

52 Tso PH, Wong YH: Molecular basis of opioid addiction: the role of signal regulation by $\mathrm{G}$ proteins. Clin Exp Pharmacol Physiol 2003; 30:307-316.

53 Sato M, Gettys TW, Lanier SM: AGS3 and signal integration by $\mathrm{G} \alpha_{\mathrm{s}}$ - and $\mathrm{G} \alpha_{\mathrm{i}}$-coupled receptors: AGS3 blocks the sensitization of adenylyl cyclase following prolonged stimulation of a $\mathrm{G} \alpha_{\mathrm{i}}$-coupled receptor by influencing processing of $\mathrm{G}_{\mathrm{i}}$. J Biol Chem 2004;279: 13375-13382.

-54 Thomas CJ, Tall GG, Adhikari A, Sprang SR: Ric-8A catalyzes guanine nucleotide exchange on $\mathrm{G \alpha}_{\mathrm{i} 1}$ bound to the GPR/GoLoco exchange inhibitor AGS3. J Biol Chem 2008; 283:23150-23160.

-55 Hofler C, Koelle MR: AGS-3 alters Caenorhabditis elegans behavior after food deprivation via RIC-8 activation of the neural G protein $G \alpha_{0}$. J Neurosci 2011;31:1155311562.
6 Sans N, Wang PY, Du Q, Petralia RS, Wang YX, Nakka S, Blumer JB, Macara IG, Wenthold RJ: mPins modulates PSD-95 and SAP102 trafficking and influences NMDA receptor surface expression. Nat Cell Biol 2005;7:1179-1190.

57 Wiser O, Qian X, Ehlers M, Ja WW, Roberts RW, Reuveny E, Jan YN, Jan LY: Modulation of basal and receptor-induced GIRK potassium channel activity and neuronal excitability by the mammalian PINS homolog LGN. Neuron 2006;50:561-573.

58 Blumer JB, Kuriyama R, Gettys TW, Lanier SM: The G-protein regulatory (GPR) motifcontaining Leu-Gly-Asn-enriched protein (LGN) and $\mathrm{G \alpha}_{\mathrm{i} 3}$ influence cortical positioning of the mitotic spindle poles at metaphase in symmetrically dividing mammalian cells. Eur J Cell Biol 2006;85:1233-1240.

59 Morin X, Jaouen F, Durbec P: Control of planar divisions by the G-protein regulator $\mathrm{LGN}$ maintains progenitors in the chick neuroepithelium. Nat Neurosci 2007;10:1440-1448.

60 Woodard GE, Huang NN, Cho H, Miki T, Tall GG, Kehrl JH: Ric-8A and $\mathrm{G}_{\mathrm{i}} \alpha$ recruit LGN, NuMA, and dynein to the cell cortex to help orient the mitotic spindle. Mol Cell Biol 2010;30:3519-3530.

-61 Kerov VS, Natochin M, Artemyev NO: Interaction of transducin- $\alpha$ with LGN, a G-protein modulator expressed in photoreceptor cells. Mol Cell Neurosci 2005;28:485-495.

62 Chia W, Yang X: Asymmetric division of Drosophila neural progenitors. Curr Opin Genet Dev 2002;12:459-464.

63 Schaefer M, Shevchenko A, Knoblich JA: A protein complex containing Inscuteable and the $\mathrm{G} \alpha$-binding protein Pins orients asymmetric cell divisions in Drosophila. Curr Biol 2000;10:353-362.

64 Schaefer M, Petronczki M, Dorner D, Forte M, Knoblich JA: Heterotrimeric G proteins direct two modes of asymmetric cell division in the Drosophila nervous system. Cell 2001; 107:183-194.

65 Bowman SK, Neumüller RA, Novatchkova M, Du Q, Knoblich JA: The Drosophila NuMA Homolog Mud regulates spindle orientation in asymmetric cell division. Dev Cell 2006;10:731-742.

66 Zhu J, Wen W, Zheng Z, Shang Y, Wei Z, Xiao Z, Pan Z, Du Q, Wang W, Zhang M: LGN/ mInsc and LGN/NuMA complex structures suggest distinct functions in asymmetric cell division for the Par3/mInsc/LGN and Gai/ LGN/NuMA pathways. Mol Cell 2011;43: 418-431.

67 Blumer JB, Bernard ML, Peterson YK, Nezu J, Chung P, Dunican DJ, Knoblich JA, Lanier SM: Interaction of activator of G-protein signaling 3 (AGS3) with LKB1, a serine/threonine kinase involved in cell polarity and cell cycle progression: phosphorylation of the Gprotein regulatory (GPR) motif as a regulatory mechanism for the interaction of GPR motifs with $\mathrm{G}_{\mathrm{i}} \alpha$. J Biol Chem 2003;278: 23217-23220.
68 Zigman M, Cayouette M, Charalambous C, Schleiffer A, Hoeller O, Dunican D, McCudden CR, Firnberg N, Barres BA, Siderovski DP, Knoblich JA: Mammalian inscuteable regulates spindle orientation and cell fate in the developing retina. Neuron 2005;48:539545 .

69 Izaki T, Kamakura S, Kohjima M, Sumimoto $\mathrm{H}$ : Two forms of human Inscuteable-related protein that links Par3 to the Pins homologues LGN and AGS3. Biochem Biophys Res Commun 2006;341:1001-1006.

70 Williams SE, Beronja S, Pasolli HA, Fuchs E: Asymmetric cell divisions promote Notchdependent epidermal differentiation. Nature 2011;470:353-358.

71 Ben-Yair R, Kahane N, Kalcheim C: LGNdependent orientation of cell divisions in the dermomyotome controls lineage segregation into muscle and dermis. Development 2011; 138:4155-4166.

72 El-Hashash AH, Warburton D: Cell polarity and spindle orientation in the distal epithelium of embryonic lung. Dev Dyn 2011;240: 441-445.

73 Guo X, Gao S: Pins homolog LGN regulates meiotic spindle organization in mouse oocytes. Cell Res 2009;19:838-848.

74 Du Q, Stukenberg PT, Macara IG: A mammalian Partner of inscuteable binds NuMA and regulates mitotic spindle organization. Nat Cell Biol 2001;3:1069-1075.

75 Kaushik R, Yu F, Chia W, Yang X, Bahri S: Subcellular localization of LGN during mitosis: evidence for its cortical localization in mitotic cell culture systems and its requirement for normal cell cycle progression. Mol Biol Cell 2003;14:3144-3155.

76 Du Q, Macara IG: Mammalian Pins is a conformational switch that links NuMA to heterotrimeric G proteins. Cell 2004;119:503516.

77 Kisurina-Evgenieva O, Mack G, Du Q, Macara I, Khodjakov A, Compton DA: Multiple mechanisms regulate NuMA dynamics at spindle poles. J Cell Sci 2004;117:6391-6400.

78 Blumer JB, Chandler LJ, Lanier SM: Expression analysis and subcellular distribution of the two G-protein regulators AGS3 and LGN indicate distinct functionality. Localization of LGN to the midbody during cytokinesis. J Biol Chem 2002;277:15897-15903.

79 Fuja TJ, Schwartz PH, Darcy D, Bryant PJ: Asymmetric localization of LGN but not AGS3, two homologs of Drosophila pins, in dividing human neural progenitor cells. J Neurosci Res 2004;75:782-793.

80 Tall GG, Krumins AM, Gilman AG: Mammalian Ric-8A (synembryn) is a heterotrimeric $\mathrm{G} \alpha$ protein guanine nucleotide exchange factor. J Biol Chem 2003;278:83568362 . 
-81 Tall GG, Gilman AG: Resistance to inhibitors of cholinesterase $8 \mathrm{~A}$ catalyzes release of $\mathrm{G} \alpha_{\mathrm{i}}-\mathrm{GTP}$ and nuclear mitotic apparatus protein (NuMA) from NuMA/LGN/ G $\alpha_{\mathrm{i}}$-GDP complexes. Proc Natl Acad Sci USA 2005; 102:16584-16589.

82 Vallee RB, Williams JC, Varma D, Barnhart LE: Dynein: an ancient motor protein involved in multiple modes of transport. J Neurobiol 2004;58:189-200.

83 Pavlos NJ, Cheng TS, Qin A, et al: Tctex-1, a novel interaction partner of Rab3D, is required for osteoclastic bone resorption. Mol Cell Biol 2011;31:1551-1564.

84 Palmer KJ, MacCarthy-Morrogh L, Smyllie N, Stephens DJ: A role for Tctex-1 (DYNLT1) in controlling primary cilium length. Eur J Cell Biol 2011;90:865-871.

85 Chuang JZ, Yeh TY, Bollati F, Conde C, Canavosio F, Caceres A, Sung CH: The dynein light chain Tctex-1 has a dynein-independent role in actin remodeling during neurite outgrowth. Dev Cell 2005;9:75-86.

-86 Sachdev P, Menon S, Kastner DB, Chuang JZ, Yeh TY, Conde C, Caceres A, Sung CH, Sakmar TP: $G$ protein $\beta \gamma$ subunit interaction with the dynein light-chain component Tctex-1 regulates neurite outgrowth. EMBO J 2007;26:2621-2632.

87 Conde C, Arias C, Robin M, Li A, Saito M, Chuang JZ, Nairn AC, Sung CH, Cáceres A: Evidence for the involvement of Lfc and Tctex-1 in axon formation. J Neurosci 2010;30: 6793-6800

88 Li A, Saito M, Chuang JZ, Tseng YY, Dedesma C, Tomizawa K, Kaitsuka T, Sung CH: Ciliary transition zone activation of phosphorylated Tctex-1 controls ciliary resorption, S-phase entry and fate of neural progenitors. Nat Cell Biol 2011;13:402-411.

\$89 Gauthier-Fisher A, Lin DC, Greeve M, Kaplan DR, Rottapel R, Miller FD: Lfc and Tctex-1 regulate the genesis of neurons from cortical precursor cells. Nat Neurosci 2009; 12:735-744.

\$0 Duguay D, Bélanger-Nelson E, Mongrain V, Beben A, Khatchadourian A, Cermakian N: Dynein light chain Tctex-type 1 modulates orexin signaling through its interaction with orexin 1 receptor. PLoS One 2011;6:e26430.
91 Nikolic M: The role of Rho GTPases and associated kinases in regulating neurite outgrowth. Int J Biochem Cell Biol 2002;34: 731-745.

\$2 Willard MD, Willard FS, Li X, Cappell SD, Snider WD, Siderovski DP: Selective role for RGS12 as a Ras/Raf/MEK scaffold in nerve growth factor-mediated differentiation. EMBO J 2007;26:2029-2040.

-93 Yang S, Li YP: RGS12 is essential for RANKL-evoked signaling for terminal differentiation of osteoclasts in vitro. J Bone Miner Res 2007;22:45-54.

-94 Schiff ML, Siderovski DP, Jordan JD, Brothers G, Snow B, De Vries L, Ortiz DF, Diversé-Pierluissi M: Tyrosine-kinase-dependent recruitment of RGS12 to the N-type calcium channel. Nature 2000;408:723727.

95 Richman RW, Strock J, Hains MD, Cabanilla NJ, Lau KK, Siderovski DP, DiverséPierluissi M: RGS12 interacts with the SNARE-binding region of the Cav2.2 calcium channel. J Biol Chem 2005;280:15211528.

96 Sambi BS, Hains MD, Waters CM, Connell MC, Willard FS, Kimple AJ, Pyne S, Siderovski DP, Pyne NJ: The effect of RGS12 on PDGF $\beta$ receptor signalling to $\mathrm{p} 42 / \mathrm{p} 44 \mathrm{mi}-$ togen activated protein kinase in mammalian cells. Cell Signal 2006;18:971-981.

$\$ 97$ Shen A, Chen M, Niu S, Sun L, Gao S, Shi S, Li X, Lv Q, Guo Z, Cheng C: Changes in mRNA for CAPON and Dexras1 in adult rat following sciatic nerve transection. J Chem Neuroanat 2008;35:85-93.

-98 Sang A, Cheng Y, Lu H, Chen D, Gao R, Shen A: Light-induced retinal ganglion cell damage in vivo involves Dexras1. Mol Vis 2011;17:134-143.

99 Tai AW, Chuang JZ, Bode C, Wolfrum U, Sung CH: Rhodopsin's carboxy-terminal cytoplasmic tail acts as a membrane receptor for cytoplasmic dynein by binding to the dynein light chain Tctex-1. Cell 1999;97:877887.

100 Gao H, Gao Y, Li X, Shen A, Yan M: Spatiotemporal patterns of dexamethasone-induced Ras protein 1 expression in the central nervous system of rats with experimental autoimmune encephalomyelitis. J Mol Neurosci 2010;41:198-209.
01 Schwendt M, McGinty JF: Amphetamine upregulates activator of G-protein signaling 1 mRNA and protein levels in rat frontal cortex: the role of dopamine and glucocorticoid receptors. Neuroscience 2010;168:96-107.

102 Li X, Cheng C, Fei M, et al: Spatiotemporal expression of Dexras1 after spinal cord transection in rats. Cell Mol Neurobiol 2008;28:371-388

103 Tseng YY, Gruzdeva N, Li A, Chuang JZ, Sung CH: Identification of the Tctex-1 regulatory element that directs expression to neural stem/progenitor cells in developing and adult brain. J Comp Neurol 2010;518: 3327-3342.

104 Dedesma C, Chuang JZ, Alfinito PD, Sung $\mathrm{CH}$ : Dynein light chain Tctex-1 identifies neural progenitors in adult brain. J Comp Neurol 2006;496:773-786.

105 Chuang JZ, Milner TA, Sung CH: Subunit heterogeneity of cytoplasmic dynein: Differential expression of $14 \mathrm{kDa}$ dynein light chains in rat hippocampus. J Neurosci 2001;21:5501-5512.

106 Mueller S, Cao X, Welker R, Wimmer E: Interaction of the poliovirus receptor CD155 with the dynein light chain Tctex-1 and its implication for poliovirus pathogenesis. J Biol Chem 2002;277:7897-7904.

107 Konno D, Shioi G, Shitamukai A, Mori A, Kiyonari H, Miyata T, Matsuzaki F: Neuroepithelial progenitors undergo LGN-dependent planar divisions to maintain selfrenewability during mammalian neurogenesis. Nat Cell Biol 2008;10:93-101.

108 López-Aranda MF, Acevedo MJ, Carballo FJ, Gutiérrez A, Khan ZU: Localization of the GoLoco motif carrier regulator of Gprotein signalling 12 and 14 proteins in monkey and rat brain. Eur J Neurosci 2006 ; 23:2971-2982.

109 Martin-McCaffrey L, Hains MD, Pritchard GA, Pajak A, Dagnino L, Siderovski DP, D'Souza SJ: Differential expression of regulator of G-protein signaling R12 subfamily members during mouse development. Dev Dyn 2005;234:438-444.

110 Wong YH, Conklin BR, Bourne HR: $\mathrm{G}_{\mathrm{z}}$-mediated hormonal inhibition of cyclic AMP accumulation. Science 1992;255:339-442. 